\title{
DINAMIKA PERKEMBANGAN WAWASAN KEBANGSAAN INDONESIA
}

Tidak ada pilihan lain, kita harus berjalan terus

Karena berhenti atau mundur, berarti hancur

(Puisi Taufik Ismail, “Kita adalah Pemilik Syah Reoublik Ini”)

Wawasan kebangsaan Indonesia seperti dikatakan oleh Roeslan Abdulgani lahir sebagai reaksi atas kolonialisme Belanda yang sangat mendominasi di bidang politik, eksploitasi ekonomi serta penetrasi budaya. Dalam aspek politik jelas bahwa wawasan kebangsaan Indonesia lahir dalam rangka menumbangkan dominasi politik Belanda untuk kemudian menggantikannya dengan system pemerintahan yang demokratis. Aspek sosial ekonomi menekankan pada penghentian eksploitasi ekonomi yang dilakukan Pemerintah Kolonial Belanda yang pada gilirannya akan membangun masysrakat baru yang bebas dari kemelaratan dan kesengsaraan. Dilihat dari aspek kultural adalah mencoba menghidupkan kembali kepribadian bangsa diselaraskan dengan perubahan zaman. Ketiga aspek tersebut merupakan satu kesatuan yang tidak dapat dipisah-pisahkan dari kontek nasionalisme Indonesia ${ }^{1}$.

Untuk melihat lebih jauh bagaimana dan permasalahan dari wawasan kebangsaan Indonesia, berturut-berturut akan kita bahas bagaimana perkembangan dari wawasan

\footnotetext{
${ }^{1}$ Pidato Roeslan Abdulgani di depan sidang konstituante pada 3 Desember 1957.
} 
kebangsaan itu sendiri, kemudian dilanjutkan dengan permasalahan integrasi bangsa yang ada sekarang dengan pemikiran jalan keluarnya.

\section{A. Perkembangan Wawasan Kebangsaan}

Dilihat dari akar sejarahnya, embrio dari munculnya wawasan kebangsaan yang kemudian melahirkan Negara nasional adalah perkembangan ekonomi dan kehidupan keagamaan sejak selesainya Perang Salib, yang menyebabkan struktur politik feodalisme tidak mampu menjawab dinamika sosial yang baru. Imperium Romawi secara bertahap runtuh, dan berdirilah berbagai kerajaan baru dengan rakyat yang relative lebih homogen serta punya kesadaran dan kepentingan nasionalnya masing-masing. Dalam bidang politik memang terdapat plurarisme, namun bangsa-bangsa baru dan Negara-negara nasional di Eropa mempunyai persamaan warisan kultural. Persamaan warisan kulturan telah memudahkan proses integrasi bangsanya masing-masing.

Wawasan kebangsaan merupakan kekuatan formatif pembentukan Negara nasional. Pembentukan Negara nasional dalam arti modern terjadi tahun 1776, ketika 13 koloni Anglo Sakson di Amerika Utara menyatakan tidak terikat lagi dengan Ratu Inggris. Dengan argument filsafati ( Declaration of Independence) bahwa Inggris telah berlaku sewenang-wenang, oleh karena itu telah kehilangan dasar legitimasinya untuk memerintah. Momen sejarah yang penting lainnya berkaitan dengan perkembangan wawasan kebangsaan dan Negara nasional adalah pemberontakan terhadap rezim monarki absolute di bawah raja Louis XIV di Perancis tahun 1789. Secara historis Negara nasional hampir selalu terbentuk sebagai puncak perjalanan panjang perlawanan terhadap 
absolutisme dan kesewenang-wenangan seperti yang terjadi di Amerika Utara dan Perancis.

Setelah menengok sejarah perkembangan wawasan kebangsaan pada Negaranegara yang lebih tua dan lebih mantap kehidupan kenegaraannya, kita akan coba lihat bagaimana perkembangan wawasan kebangsaan di negara kita tercinta, Indonesia. Suatu kenyataan sejarah, bahwa wawasan kebangsaan bukanlah suatu konsep politik yang pertama kali lahir di Indonesia. Kesadaran kebangsaan ini lahir dari persepsi pemimpin pergerakan kemerdekaan yang telah berpendidikan Barat dalam perjuangan menentang penjajahan Belanda. Sumbangan dari local genius bangsa Indonesia barangkali terletak pada kemampuan bangsa ini untuk mengadopsi serta mengadaptasi berbagai konsep yang datang dari luar dan menjadikannya sebagai bagian integral dari system nilai masyarakat sendiri $^{2}$.

Proses penyatuan wilayah Nusantara ke dalam suatu kesatuan politik pada awalnya adalah suatu proses ekspansi Pemerintah Kolonial Belanda untuk memperluas wilayah jajahannya. Wilayah jajahan Belanda di nusantara kemudian dijadikan klaim wilayah bagi wawasan kebangsaan di Indonesia. Wawasan Kebangsaan lahir sebagai kekuatan yang berhadapan dengan idiologi kolonial, di mana tujuannya untuk membebaskan diri dari belenggu penjajahan.

Wawasan kebangsaan di Indonesia memang baru dikenal setelah terjadi kontak di antara kaum terpelajar Indonesia dengan peradaban Eropa dan Amerika. Ide wawasan

2 Bangsa ini punya kemampuan untuk mengadopsi berbagai konsep dan pemikiran yang disesuaikan dengan kondisi yang ada di Indonesia. Lebih jauh lihat Saafroedin Bahar, “Integrasi Bangsa Indonesia”, Makalah dalam seminar nasional Negara dalam Sejarah nasional, di Jakarta, tanggal 31 agustus 1999, Hal 11. 
kebangsaan lahir di kalangan kaum intelektual. Kemudian ide ini disebarluaskan ke kalangan masyarakat dalam rangka menghadapi kekuatan asing yang berbeda dari segi ras dan agamanya. Agama Islam telah menyatukan berbagai kelompok etnis dan kultural ke dalam pendangan keagamaan, sistem hukum dan institusi sosial yang relative sama. Dalam komunitas etnis muslim Indonesia, batas-batas politik bukan sesuatu yang menghalangi kehidupan actual sehari-hari. Islam juga telah mengembangkan bahasa melayu yang semula hanya digunakan kelomok etnis yang relative kecil di Riau, menjadi lingua franca berbagai kelompok etnis termasuk Jawa ${ }^{3}$.

Agama Islam yang telah menjadi fokus kesetiaan para penganutnya, telah mengembangkan kesadaran akan pengalaman sejarah yang sama. Secara doktrinal menurut pandangan Islam, kolonialis Belanda adalah kafir yang harus dimusuhi dan diperangi. Islam menjadi salah satu faktor pendorong munculnya wawasan kebangsaan, setelah sebelumnya berhasil menjinakkan sentimen etnisitas untuk kemudian menumbuhkan loyalitas kepada etnisitas lebih tinggi, yang dalam masa lebih akhir terwujud dalam bentuk Negara Bangsa ( nation State $)^{4}$.

Dilihat dari perjalanan sejarahnya perkembangan wawasan kebangsaan dapat kita lihat dalam2 fase perkembangan. Fase pertama, tahun 1908-1928. Tanggal 20 Mei 1908 kita akui sebagai hari Kebangkitan Nasional, karena Boedi Oetomo dapat kita pandang sebagai pelopor Kebangkitan Nasional meskipun dalam kenyataannya masih bertumpu

${ }^{3}$ S.M.N. Al- Attas, Islam dalam Sejarah dan Kebudayaan Melayu, Bandung : Mizan, 1987.

4 Azyumardi Azra, “ Nasionalisme, Etnisitas dan Islam dalam politik Kontemporer”, Makalah dalam Seminar Nasional, Negara dalam Sejarah Indonesia, di Jakarta 31 Agustus 1999. 
pada 'konsep Jawa” ${ }^{5}$. Selama rentang waktu 20 tahun lahirlah organisasi-organisasi politik sebagai alat baru untuk merumuskan tujuan yang hendak dicapai ${ }^{6}$. Para pemimpin politik dan golongan terpelajar mulai mengenal cara-cara bertukar pikiran yang baik untuk merumuskan tujuan. Dialog dilakukan dalam rangka mencapai konsensus atau kesepakatan bersama. Dalam fase pertama ini melahirkan kesepakatan menggunakan sebutan sebagai satu bangsa baru yaitu Indonesia.

Indische Partij yang lahir tahun 1911, merupakan partai yang menganut wawasan yang supra-etnik. Tonggak sejarah yang penting berikutnya bagi perkembangan wawasan kebangsaan adalah manifesto politik oleh organisasi Perhimpunan Indonesia (PI) di negeri Belanda. Manifesto politik tahun 1924 merupakan penegasan dari tujuan politik PI, bahwa kemerdekaan penuh bagi bangsa Indonesia akan diperoleh apabila ada aksi massa yang dilakukan serentak oleh seluruh kaum nasionalis dan rakyat berdasar atas kekuatan sendiri ${ }^{7}$.

Penggunaan nama baru “Indonesia” merupakan hal yang penting bagi tumbuh dan berkembangnya wawasan kebangsaan. Selain nama organisasi, diganti pula istilah-istilah

${ }^{5}$ Dalam visi Jawa ini, integrasi bangsa Indonesia akan selalu dipahami sebagai dominasi kultur Jawa terhadap kultur masyarakat Indonesia lainnya. Baca lebih lanjut, Soemarsid Moertono, 1985, Negara dan Usaha Bina Negara : Studi tentang Masa Mataram II Abad XVI sampai XIX, Yogyakarta : UGM Press.

${ }^{6}$ Selama 3 abad sebelumnya perlawanan terhadap Belanda dilakukan secara sporadic, terpisah-pisah dengan organisasi perang tradisional yang mengandalkan otot dan fisik. 45-46.

${ }^{7}$ Ali Sastroamidjojo, 1974, Tonggak-tonggak di perjalananku, Jakarta: Kinta, hal. 
yang masih berbau kolonial, misalnya majalah PI "Hindia Putra" menjadi "Indonesia Merdeka”8. Lebih jauh Ahmad Subardjo menjelaskan:

"Karena tujuan kami kemerdekaan, tanah air dan istilah Hindia Belanda pada saat tercapainya kemerdekaan nanti akan hilang pula. Bukan itu saja yang menjadi alas an untuk mencari nama pengenal untuk tanah air, sering kami menghadapi orang Perancis, Jerman atau bangsa Eropa lainnya dan harus menjawab pertanyaan, Tuan asal dari mana"9.

Tokoh komunis nasional Ibrahim Datuk Tan Malaka tahun 1925 juga menerbitkan buku kecilnya Naar de Republiek Indonesia, yang secara jelas menunjukkan adanya kesadaran kebangsaan yang menginginkan terbentuknya sebuah Negara nasional di wilayah Negara kolonial Hindia Belanda ${ }^{10}$. Berdirinya Partai Nasional Indonesia tahun 1927 di Bandung, dicanangkannya Sumpah Pemuda 28 Oktober 1928 merupakan kelanjutan dari peristiwa-peristiwa sebelumnya. Di dalam "Sumpah Pemuda” disetujui tiga pengakuan, satu tanah air, Indonesia; satu bangsa, Indonesia dan satu bahasa, bahasa persatuan bahasa Indonesia. Dalam kumpulan sajaknya yang berjudul Indonesia Tumpah Darahku (terbit 1929), Yamin mengungkapkan cerminan keyakinan di kalangan kaum terpelajar muda bahwa pertama-tama mereka adalah orang Indonesia, dan baru yang kedua, orang Minangkabau, Batak, Jawa, Kristen, Muslim atau apa saja ${ }^{11}$. Mulai tahun

8 Sudiyo,1989, Perhimpunan Indonesia sampai dengan Lahirnya Sumpah Pemuda, Jakarta: Bina Aksara, hal. 41.

${ }^{9}$ Ahmad Subardjo, 1978, Kesadaran Nasional ( otobiografi), Jakarta : Gunung Agung, hal.25.

${ }^{10}$ Harry A. poeze, 1999, Pergulatan Menuju Republik ; Tan Malaka 1925-1945, Jakarta : Pustaka Utama Grafiti, hal. 4. 282.

11 M.C. Ricklefs, 1995, Sejarah Indonesia Modem, Yogyakarta, UGM Press, hal 
1928 telah disepakati nama Indonesia sebagai simbul baru sebuah bangsa yang sedang diperjuangkan dan menjadi Indonesia, sama sekali bukanlah paksaan.

Fase kedua adalah tahun 1928-1945. Dalam fase ini simbul hidup bersama yaitu Indonesia, digunakan secara luas dalam rangka perjuangan melawan Belanda. Tindakan represif yang keras dari Pemerintah Kolonial Belanda menyebabkan gerakan nasionalis mengalami kemunduran hebat. Tokoh-tokoh pergerakan banyak yang dihukum berat seperti, M. Hatta, Syahrir juga Soekarno. Meskipun dalam bidang politik mengalami kemunduran, namun wawasan kebangsaan tetap dikembangkan melalui bidang kebudayaan dengan timbulnya pemikiran mengenai kebijakan dan strategi dasar yang akan dikembangkan untuk membangun Indonesia di masa depan.

Berbeda dengan Belanda, kebijakan Jepang tahun 1942-1945 terhadap rakyat Indonesia mempunyai dua prioritas yaitu menghapuskan pengaruh-pengaruh Barat di kalangan rakyat dan memobilisasi rakyat demi kemenangan Jepang. Jepang berkepentingan dengan bangkitnya kembali semangat kebangsaan rakyat Indonesia, sebagai salah satu sarana strategis dalam mempertajam sentimen anti Belanda di kalangan masyarakat Indonesia dan mendorong penyebaran wawasan kebangsaan Indonesia di kalangan rakyat. Bahasa Indonesia juga menjadi sarana bahasa yang utama untuk propaganda sehingga memperkokoh status bahasa Indonesia sebagai bahasa nasional.

Balatentara Jepang memberikan dasar militer pada bangsa Indonesia dengan memberikan latihan militer yang bersifat massal kepada penduduk. Pasukan paramiliter hasil latihan dari Jepang merupakan tulang punggung bagi kelangsungan hidup Republik Indonesia setelah proklamasi kemerdekaan tanggal 17 Agustus 1945. Balatentara Jepang 
juga memberi kesempatan, kemudahan dan bantuan untuk bangkitnya wawasan kebangsaan Indonesia dengan gerakan nasionalisme serta aspirasi Islam. Lebih jauh juga memberi kesembatan bangsa ini menyusun rumusan dasar Negara Indonesia modern yang akan terbentuk kemudian tentunya kalau Jepang menang perang.

Negara kesatuan adalah pilihan para faunding father.Republik Indonesia yang mendapat dukungan kuat oleh rakyat Indonesia ${ }^{12}$. Bangsa Indonesia memang sudah tidak ragu dengan pilihan mereka tentang Negara kesatuan ini. Dasar-dasar wawasan kebangsaan cukup kuat karena bangsa Indonesia terbentuk lebih dulu dari Indonesia sehingga nasionalisme berkembang wajar dan tanpa paksaan. Pernyataan bahwa perbedaan budaya dan etnis akan menjadi penghambat pembentukan nasionalisme ${ }^{13}$ tidak berlaku dalam membahas nasionalisme di Indonesia

\section{B. Permasalahan Integrasi Nasional}

Dalam usia yang ke 62 tahun, sebagai bangsa-bangsa yang merdeka dalam rangka melindungi segenap bangsa Indonesia dan seluruh tumpah darah Indonesia, memajukan kesejahteraan umum, mencerdaskan kehidupan bangsa, serta ikut melaksanakan ketertiban dunia berdasar atas kemerdekaan, perdamaian abadi dan keadilan sosial, masih

12 George Mact.Kahin, 1970,Nationalism and Revolution in Indonesia, Ithaca, New York : Cornell University Press, hal 450.

${ }^{13}$ Pembentukan identitas dan kesatuan nasional di Negara-negara Asia Tenggara dihambat oleh perbedaan-perbedaan tradisiona, budaya dan etnis yang ada diantara kelompok-kelompok masyarakat di kawasan tersebut,, Donald G. McCloud, 1986, System and Process in Southeast Asia. The Evolution of Region, Boulder, CO: Westview, hal.137. 
diperlukan sumber daya nasional untuk membangun dan memantapkan kesadaran dan kesetiaan terhadap Negara nasional, Indonesia.

Integrasi bangsa yang selama ini dengan susah payah dibangun selalu dihadapkan pada faktor disintegratif yang ada dalam masyarakat. Faktor disintegratif barkait erat dengan sektor tradisional masyarakat yaitu Suku, Agama, Ras atau Etnik (SARA), masalah konflik terpendam antara umat Islam dan Kristen muncul kembali ke permukaan. Masalah yang relative tidak muncul pada masa melawan penjajah Belanda. Pada zaman kolonial karena menghadapi musuh yang sama, mereka dapat saling bahu membahu. Persaingan memperoleh alokasi sumber daya yang terbatas telah menyebabkan fihak yang merasa terdesak mengibarkan bendera agama yang dianutnya, misalnya di Irian Jaya.

Menyangkut masalah etnisitas, Indonesia memiliki potensi disintegratif yang tinggi. Secara etnis, Indonesia terdiri atas lebih dari 300 kelompok etnis berbeda lengkap dengan identitas kulturalnya sendiri, yang berbicara dengan lebih dari 250 bahasa yang berbeda pula. Etnisitas juga tidak punya relevansi untuk diangkat sebagai tema politik. Gerakan Hassan Tiro di Aceh memang berusaha mengekplotasi sentiment etnisitas Aceh berhadapan dengan apa yang disebutnya kolonialisme Jawa. Bahkan kemudian mengangkat nasionalisme Sumatera dengan konsep Sumatera merdeka, yang tidak mendapat dukungan baik secara histories maupun sosiologis.

Faktor disitegratif karena SARA ini, harus kita minimalisir dengan usaha menyegarkan kembali kesadaran tentang proses panjang sejarah pembentukan bangsa dan Negara nasional Indonesia. Tradisi Austronesia sebagai unsur-unsur kultural bersama yang melatarbelakangi kemajemukan masyarakat perlu lebih dikukuhkan. 
Masalah berikutnya yang sedang kita hadapi bersama adalah kecenderungan meningkatnya separatisme di daerah. Ada dua propinsi yang terang-terangan menyatakan ingin merdeka yaitu Aceh dan Riau. Kedua propinsi memang dikenal sebagai daerah kaya dan penghasil devisa Negara dengan minyak bumi dan gasnya. Di Aceh tuntutan telah sampai pada tingkat perlawanan bersenjata yang telah pula memakan banyak kurban. Di Riau baru pada tingkat pernyataan ingin merdeka oleh sekelompok kecil intelektual.

Untuk dapat mengatasi masalah sparatisme ini, pemerintah haruslah menghormati perbedaan-perbedaan yang ada di daerah serta memperhatikan kepentingan-kepentingan daerah dan rakyat yang hidup di sana. Kontrol yang kuat dari DPR, Pers, dan rakyat sangat perlu, agar pemerintah dan elite politik tidak menonjolkan kepentingannya sendiri yang dapat merugikan daerah. Asas yang tercantum dalam Undang-undang No 22 dan 25 tahun 1999 mengenai hubungan dan pembagian wewenang antara Pemerintah pusat dan pemerintah daerah serta perimbangan keuangan, mungkin merupakan salah satu bentuk formula yang dapat membantu mewujudkan adanya persatuan dan kesatuan nasional, dengan memberi ruang gerak yang cukup bagi kemajemukan di Indonesia. Pemerintah juga harus melanjutkan sikap yang lebih akomodatif dalam upaya menyelesaikan protes masyarakat lokal terhadap berbagai ketidakadilan yang telah dialaminya di bawah rezim terdahulu. Pendekatan security, perlu diletakkan dalam kontek yang lebih luas yang juga harus memperhitungkan kemajemukan suku, agama, ras atau etnik dari penduduk Indonesia. Pemerintah pusat perlu mengetahui secara mendalam latar belakang sejarah integrasi serta ciri khas masalah kontemporer di daerah. 
Masalah korupsi, kolusi dan nepotisme juga telah menjadi penyebab munculnya disintegrasi bangsa. KKN menjadi masalah besar di Negara kita karena tidak hanya merusak ekonomi tetapi juga merusak moral bangsa. Keadaan yang sempat parah ini memaksa Majelis Permusyawaratan Rakyat mengeluarkan ketetapan khusus dengan meninstruksikan presiden yang sedang memerintah untuk menuntut seorang mantan presiden atas tuduhan telah melakukan $\mathrm{KKN}^{14}$.

Penegakan hukum terhadap masalah KKN yang melibatkan "oknum pemerintah dan aparat penegak hukum lainnya, sering terlihat tidak punya kekuatan sama sekali. Mantan Presiden Soeharto dan kroni-kroninya msih dapat bernafas lega karena seakanakan mereka kebal hukum dan tidak tersentuh sama sekali oleh hokum.

Untuk mengatasi hal tersebut, supremasi hukum harus ditegakkan serta ditingkatkan kembali wibawa pemerintah yang selama ini terpuruk. Supremasi hukum ditegakkan dengan cara melaksanakan aturan yang telah disepakati bersama sekaligus mengembangkan norma hukum positif yang sesuai dengan kebutuhan. Menerapkan asas pembuktian terbalik, mungkin merupakan solusi yang tepat untuk memberantas KKN. Asas pembuktian terbalik seperti yang sudah dilaksanakan di banyak Negara seperti Singapura, Malaysia, Hongkong dan sebagainya ternyata mampu meminimalisir masalah KKN di Negara tersebut. UU No.3 tahun 1971 tentang pemberantasan korupsi, kiranya perlu segera disempurnakan sesuai dengan kebutuhan saat ini dan yang akan datang. Dengan perangkat hukum yang kuat dan memadai, kiranya pengadilan akan mampu membersihkan mereka yang benar-benar bersih dan menghukum mereka yang benarbenar bersalah.

${ }^{14}$ Tap MPR No XI/MPR/1998 
Krisis kepercayaan terhadap pengelola negeri ini telah pula menurunkan kebanggaan terhadap bangsa dan kebangsaan Indonesia. Kebanggaan sebagai bangsa bangsa adalah satu sendi yang menopang seluruh bangunan kebangsaan serta keberadaan Negara nasional Indonesia. Untuk itu diperlukan suatu perenungan bersama seluruh komponen bangsa dalam rangka menyegarkan kembali kesadaran tentang wawasan kebangsaan dan proses panjang sejarah pembentukan bangsa dan Negara Indonesia yang sama-samu kita cintai.

\section{Penutup.}

Di dalam suasana bangsa-bangsa yang sedang dilanda berdagai krisis, seharusnya kita semua terdorong untuk melakukan evaluasi diri untuk tidak berhenti atau mundur, karena berarti hancur (lihat puisi di bagian awal ). Kita harus menemukan alternative terbaik untuk bias segera keluar dari berbagai permasalahan yang mengancam integrasi bangsa. Kita beruntung karena kita hidup pada zaman ini, sehingga kita tidak hanya menjadi penonton dan pengamat sejarah saja, tetapi juga sebagai aktor dan pembentuk sejarah betapapun kecilnya peran yang dapat kita jalani.

\section{DAFTAR PUSTAKA}

Ahmad Subardjo, (1978). Kesadaran Nasional ( otobiografi), Jakarta : Gunung Agung.

Al- Attas, S.M.N., (1987). Islam dalam Sejarah dan Kebudayaan Melayu, Bandung : Mizan.

Ali Sastroamidjojo, (1974). Tonggak-tonggak di perjalananku, Jakarta: Kinta 
Azyumardi Azra, (1999). “ Nasionalisme, Etnisitas dan Islam dalam politik Kontemporer”, Makalah dalam Seminar Nasional, Negara dalam Sejarah Indonesia, di Jakarta 31 Agustus.

Donald G. McCloud, (1986). System and Process in Southeast Asia. The Evolution of Region, Boulder, CO: Westview

George Mac..Kahin, (1970).Nationalism and Revolution in Indonesia, Ithaca, New York : Cornell University Press

Harry A. poeze, (1999). Pergulatan Menuju Republik ; Tan Malaka 1925-1945, Jakarta : Pustaka Utama Grafiti.

Pidato Roeslan Abdulgani di depan sidang konstituante pada 3 Desember 1957.

Saafroedin Bahar, (1999). "Integrasi Bangsa Indonesia”, Makalah dalam seminar nasional Negara dalam Sejarah nasional, di Jakarta, tanggal 31 Agustus.

Ricklefs, M.C., (1995). Sejarah Indonesia Modem, Yogyakarta, UGM Press.

Soemarsid Moertono, (1985). Negara dan Usaha Bina Negara : Studi tentang Masa Mataram II Abad XVI sampai XIX, Yogyakarta : UGM Press.

Sudiyo, (1989). Perhimpunan Indonesia sampai dengan Lahirnya Sumpah Pemuda, Jakarta: Bina Aksara.

Tap MPR No XI/MPR/1998 